UDC 341.322.3(439:497.1)

341.49(439:497.1)

343.15:344(439:497.1)

Александар Касаш

Универзитет у Новом Саду

Филозофски факултет

Одсек за историју

alkasas@yahoo.com
Оригинални научни рад

примљено: 15. јун 2011

прихваћено: 1. октобар 2011

\title{
ПРОТОКОЛ О ИЗРУЧЕЊУ РАТНИХ ЗЛОЧИНАЦА ИЗМЕБУ ДЕМОКРАТСКЕ ФЕДЕРАТИВНЕ ЈУГОСЛАВИЈЕ И МАЂАРСКЕ, ИЗ НОВЕМБРА 1945. ГОДИНЕ*
}

Сажетак: У раду се анализирају разлози до којих је дошло до сарадње ДФЈ и мађарске државе о изручењу ратних злочинаца, посебно, главноодговорних за рацију из јануара 1942. године, који су оптерећивали југословенско-мађарске односе на крају Другог светског рата, посебно Министарстава унутрашњих послова двеју држава и изручења ратних злочинаца за суђење на оним територијама где су злочини чињени, а посебно на сарадњи двеју држава по том питању, када још нису били успостављени дипломатски односи.

Кључне речи: мађарско-југословенски односи на крају Другог светског рата, рација 1942. године, ратни злочини, протокол о изручењу ратних злочинаца између ДФЈ и Мађарске.

Завршетак Другог светског рата отворио је и питање појединачне и колективне кривице за ратне злочине почињене у јужној Бачкој јануара 1942. године. Мађарско-југословенске (српске) односе, у време припрема за Мировну конференцију, посебно је оптерећивало страдање преко четири хиљаде Срба, Јевреја и Рома током Другог светског рата. Још 17. септембра 1944. године основана је Покрајинска комисија за утврђивање злочина окупатора и његових помагача. Тада се оснивају и тзв. Већа статистичара која су имала задатак да прикупе податке о свим злочинима на територији Војводине. Главни народноослободилачки одбор придавао је раду на тим пословима посебан општенародни, политички и национални значај. Октобра се доноси посебан Правилник о раду Комисије. Међутим, и поред прецизних упутстава и правила у Војводини, посебно у Бачкој, јавили су се примери личне освете, али и самовоље Органа за заштиту народа (O3Н), који нису најбоље познавали прилике у вишенационалној Војводини. ${ }^{1}$ Проблем кажњавања оних који

\footnotetext{
* Рад је настао као фазни резултат републичког пројекта број 177002 под називом Војвођански простор $у$ контексту европске историје.

${ }^{1}$ Стенографски записници са суђења главноодговорнима за рацију у јужној Бачкој 1942. године, (Аутор уводних напомена, предговора и приређивач Александар Касаш), Нови Сад 2008, 19-20.
} 
су сматрани за главне и одговорне за злочине био је на војвођанским просторима, посебно у Бачкој, присутан већ од самог ослобођења октобра 1944. године, од времена увођења Војне управе за Банат, Бачку и Барању чији је задатак, између осталог, био и кажњавање Мађара за чињења у рацији јануара 1942. године. Мада су многи од њих побегли са тих простора при крају рата, још септембра 1944. године, из страха од „српске и бољшевичке одмазде“. Том приликом несумњиво је било случајева личне освете, када је страдало невино становништво мађарске националности чији је број и данас непознат и њиме се „манипулише из политичких разлога“. Ипак, историјска је чињеница да је комунистичка власт у Војводини, без обзира на то да „победници на крају рата имају своју истину“, ипак покушавала да да̂ какав-такав правни карактер и основ, али је засигурно била присутна чињеница и да се желела дати сатисфакција преживелим члановима страдалих (српских) породица у јужној Бачкој, посебно у Шајкашкој. Зато народна власт, већ средином новембра 1944. године, доноси наредбу о забрани уништавања докумената у општинским архивама и регистратурама, јер су она потребна као доказни материјал у будућим суђењима за ратне злочине. Већ 17. јануара 1945. године, првих дана након ослобођења Будимпеште, Трива Милитар, као члан Анкетне комисије при Комисији за утврђивање злочина окупатора и његових помагача у Војводини, и добар зналац мађарског језика и војвођанских међунационалних односа и прилика, уз совјетску пуномоћ боравио је у главном граду Мађарске са задатком да прегледа тамошње архиве и прикупи што више података за предстојећа суђења ратним злочнцима, али и за писање Елабората ${ }^{2}$ који је требало да послужи југословенској делегацији на будућој Мировној конференцији. На овој конференцији требало је да и Мађарска буде кажњена као савезник пораженог Хитлеровог савезника. Присуство Црвене армије на територији Мађарске омогућило је органима ОЗН-е интензивнији рад на проналажењу, хапшењу и привођењу окривљених народном суду, али је вредно истаћи да су им касније судили војни судови. Тако се, када је рат већ био завршен на територији Мађарске, велики жупан Бач-бодрошке жупаније др Лео Деак пријавио совјетским властима у Будимпешти 11. марта 1945. године, а на тражење југословенских органа. Највероватније је и он, као и други, сматрао да је био носилац цивилне власти у успостављању оних историјских ситуација које су прекинуте 1918. године и да је његова одговорност знатно мања него одговорност војних органа, посебно про немачки оријентисаних мађарских официра.

Завршетак Другог светског рата условио је да се разреши проблем изручења оних за које се сматрало да припадају категорији најодговорнијих ратних злочинаца, односно да Мађарска и новоформирана југословенска држава ДФЈ, тј. Министарства унутрашњих послова ових двеју држава, отпочну званичне разговоре о изручењу ових лица.

\footnotetext{
${ }^{2}$ Елаборат је штампан следеће године. Према мојим вишегодишњим истраживањима овај званично објављени Елаборат је мало умеренија верзија. Разлог се можда може наћи у чињеници да нова комунистичка Југославија није желела да још више отежава положај мађарских комуниста у тој држави приликом доласка на власт уз помоћ Совјета.
} 
Разговор је отпочео 8. новембра 1945. године у Министарству унутрашњих послова Демократске Федеративне Југославије између представника нашег Министарства међу којима су били председник Комисије и помоћник министра Милош Радовић, начелник Одељења Ђура Станковић и шеф Одсека Светозар Чобрда. Сви су они имали пуномоћ Министарства бр. Каб 1349/45. Представници мађарске стране били су др Ендре Хортобађи, заменик шефа Политичког одељења начелника Комесаријата мађарске државне полиције у Будимпешти, и чиновницика Отоа Хонигсберга и Иштавана Денеша, који су имали пуномоћја свог Министарства од 1. новембра 1945. године бр. 143.323/45 И.Б.М. IV/12. ${ }^{3}$ Овај разговор иницирала је мађарска страна, а предмет разговора био је да се:

„1. Успостави веза са Југословенским полицијским и политичко-полицијским властима. 2. Помоћу Југословенских полицијских и полицијско-политичких власти сакупити податке против оних мађарских јавних службеника (полицајаца, жандарма, агената, протушпијунаже - К остаљаца ${ }^{4}$ и уопште свих других војних и грађанских лица (који су били у служби у Војвођанским местима, а који су побегли за Мађарску. 3. Донети евентуално већ сакупљене конкретне податке о таквим лицима. 4. Сакупити податке о ратним злочинцима Југословенске народности који се крију по Мађарској. Преговори су отпочели у 10 сати са изменом пуномоћја и међусобних поздрава. Након тога према предложеним тачкама утврдио се дневни ред. Отпочело се са дискусијом: Представник Мађарске изјављује да је Мађарска Влада већ до сада дала похватати велики број ратних злочинаца, а да је извјесне од тих већ предала Југославији на привођење заслуженој казни. Многи се још налазе у рукама Мађарских власти, те да је Министар Унутрашњих послова Мађарске изразио да би било пожељно да по томе питању допутује у Будимпешту г. Министар Унутрашњих Послова ДФЈ, или његов опуномоћеник који би са Мађарским Министарством уредили питање предаје и уопће даљег поступка са тим ратним злочинцима. На ово одговара Представник Југословенске делегације друг Радовић Милош, да код Државне Комисије за Утврђивање ратних злочина, већ постоји скоро читави елаборат у погледу утврђивања кривице и одговорности великог броја Мађарских грађана, из којег се елабората може потпуно и у великој мјери питање кажњавања и привођења тих ратних злочинаца извршити. Тај елаборат треба да садржи двије категорије ратних злочинаца, т.j. оних који су већ као ратни злочинци окатегорисани и регистровани код Међународне Комисије, и оних који су починили злочине у нашој земљи, и за које је одговорност несумњиво утврђена, а да нису још регистровани код Међународне комисије. Износи значај и потребу брзог и ефикасног кажњавања свих ратних злочина, њихово хватање и откривање, како у интересу Југословенског тако и у интересу Мађарског Народа. Тај Меморандум је већ спремљен и треба да у најскорије вријеме буде упућен Народној Влади Мађарске. Меморандум ће носити одређена делегација од двојице лица, који требају бити веза између Власти у Мађарској и наше Владе.

Сматра да се ова друга категорија ратних злочинаца, наиме тих који још нису регистровани код Међународне комисије, треба посредством Мађарске Владе што прије привести заслуженој казни и предати Југословенским Властима на суђење.

Све бирократске и формалне поступке, који би одуговлачили поступак треба и једна и друга земља у интересу правде избјећи. овог питања.

Сматра да ће и даљња сарадња између двију земаља у велико овисити о правилном ријешењу

Овлаштени Представник Мађарског Министарства, изјављује, да уколико му је познато, да Мађарска Влада стоји на становишту што бржег и ефикаснијег поступка, против свих ратних злочинаца, и да ће се они у том погледу апсолутно руководити брзим поступком.

Вођа делегације Мађарске предлаже да би због проналажења ратних злочинаца и њиховог откривања они жељели послати двојицу полицијских агената у нашу земљу, ради проналаска ратних

\footnotetext{
${ }^{3}$ Архив Југославије Београд, 110-746-803.

${ }^{4}$ Тзв. поверљиви људи, који су најчешће били доушници.
} 
злочинаца и откривања злочина у вези са истрагама против извјесних злочинаца који се налазе у Мађарској а злочине су починили у Југославији. Каже да би се ово односило у главном на мале ратне злочинце, жандарме, полицајце и друге мање личности, који би се на овај начин откривали и проналазили.

Помоћник Министра Унутрашњих послова ДФЈ Радовић поводом тога изјављује да је то апсолутно непотребно јер да наши органи власти имаду такове везе са Мађарским народом у нашој земљи и да ће наши органи апсолутно све потешкоће у том погледу пребродити, прикупити све податке, обавештења и информације, још потпуније него што би то могли односна двојица полицијских агената Мађарске полиције. Други делегат Станковић, надопуњује помоћника Министра тиме да се у погледу изручивања ноторних злочинаца, имаде право изручивања по Међународним правилима, за изручивање злочинаца Југословенске народности, да се требају такођер изручивати без неких посебних формалности, а да се овде ради о злочинцима који су мање личности.

На то Мађарски делегат изјављује да се баш о тим мањим злочинцима и ради, који су се склонили односно који живу у Мађарској, а о њима се нема довољних података. Каже да они мисле да би се на овај начин, изашиљањем двојице својих људи за прикупљање података у сарадњи са нашим органима безбедности, поступци убрзали и постали ефикаснији. Сматра да би у том погледу требало избјећи све потребне међународне формалности и дипломатске форме.

Друг Станковић, изјављује да ми неби одустали од свога схватања у том погледу и да би у томе Мађарска Влада, давањем података из својих архива и администрације, о учешћу одређених лица у акцијама и дјелима која су се мјерила са злочином, давањем података из тих архива, тко, гдје и када је учествовао, по чијој заповјести, када и на који начин. Шта је учинио итд. потпуно задовољила потреба информација и обавештења за утврђење свих тих злочинаца и да би их на основу тога наши органи могли апсолутно утврдити и аргументирати.

Друг помоћник Министра надопуњује да би случај сарадње органа безбедности једне и друге земље могао да долази до изражаја само у извјесним конкретним случајевима повремено, што би се могло утврђивати кратким путем, ради кратког договора о поступку у извесном случају и сл.

Након тога се Мађарска делегација слаже са мишљењем Југословенске делегације, једино сматрају да би требало већ сад одредити лица која би у тим случајевима била у вези.

Помоћник Министра Југославије, изјављује да ће двојица лица који буду носили поменути елаборат Влади Мађарске имати овлашћења и за сав остали рад по овоме питању, те тако и за везу и свим конкретним случајевима. Њихова имена да им можемо доставити накнадно.

Овлаштени Делегат Мађарске упознава комисију, да је у Мађарској при сваком надлештву формирана Контролна комисија, за испитивање критеријума свих државних службеника, који се налазе у државној служби, који су били па напустили држ. службу, кои се повраћају у исту или који желе да ступе у исту. Тако у вези тога долази из Немачке велики број бивших жандарма и полицајаца, који су раније службовали у Војводини, те се поновно желе вратити у Мађарску држ. службу. Комисија испитује, али у случајевима да нема неких доказа о учешћу у злочинима или нешто друго да га комисија предлаже за службу.

Због тога сматра да би контролну комисију требало упознати са свим случајевима злочина и лицима која су у тим злочинима учествовали како би се могло не само избећи од увлачења фашиста и злочинаца у држ. апарат Мађарске, већ и како би се они који су починили злочине могли подврћи казни.

Помоћник Министра ДФЈ износи да наши органи власти у свим случајевима тражења информација од стане Мађарских власти истима излазе у сусрет, а да ће излазити и у будуће.

Други делегат Станковић, надопуњује да се сви ти подаци за Мађарске контролне комисије, могу црпети из Српске и елабората који ће бити ускоро Мађарској Влади од Наше Владе, као и из каснијих надопуна тога елабората.

Вођа Мађарске делегације поновно предлаже да би у овим случајевима, као и вези ранијег њиховог предлога и мишљења било добро да дође један њихов орган, иначе поручник Ј.А. који познаје мађарски језик па да би он директно код Мађарског становништва, испитивао и настојао ући у траг свим злочинима и свим злочинцима - Мађарским фашистима, те да би на тај начин се олакшао посао.

Помоћник Министра ДФЈ. износи да сматра да то није згодно ни политички у односу на Мађарски народ у Југославији, који о новој Југославији треба да стекне друго мишљење, него о старој, и да та стара полицијска метода апсолутно није потребна. Понавља да ће органи наших власти са 
родољубивим мађарским становништвом и антифашистичким особама, ући у траг свим злочинима из времена окупације. Надаље конкретизује досадашњи ток дискусије, како следи: 1/. Народна Влада Мађарске, ће добити од Владе ДФЈ. односно од Државне Комисије за утврђивање ратних злочина, елаборат са потребним доказима и аргументацијом већег броја злочинаца Мађарских грађана. 2/. Тај досије донијети ће двојица представника Владе ДФЈ. 3/. Сарадња по овом питању да се и даље одвија преко друга Мајора J.А. у делегацији при Савезничкој Контролној Комисији, у вези са двојицом представника под тач. 2. 4/. Веза и сарадња обију земаља у овом погледу треба да буде директна као и до сада, но још чвршћа и чешћа него до сада, без бирокрације и непотребних формалности. 5/ О лицима која ће интересовати Мађарску владу, а која небуду у реченом досијеу или у накнадним извештајима, да траже преко нашег делегата у Мађарској, по чему ће наши органи поступати, а евентуално успостављати и лични контакт.

Ово до сада би био начин успоставе везе по криминалитету политичког карактера, док би такођер требало извјесне ствари расправити по питању осталог криминалитета и његовог међусобног сузбијања.

Након тога Помоћник Радовић, предаје извод из списака ратних злочина у Војводини, с тим да ће све остало бити садржано у досијеу.

Мађарски делегат моли да се у Будим Пешту пошаље лице у делегацији са меморандумом, које располаже са знањем мађарског језика.

Потом се осврће на публикацију коминикеа, те наша делегација износи сувишност тога, с обзиром на карактер самих преговора и начин на који су дошли, као и чињеницу да још не постоје дипломатски односи између две земље. Наши представници констатују да сам текст имаде лијеп израз и да би као такав могао бити поздрављен од нашег народа, али да публикација из предњих разлога није потребна.

Прелази се на дискусију у погледу сарадње на привредном пољу, сузбијања изношења валуте из једне земље у другу, фалсификовање новчаница и хартија од ваљаности, преношење намирница итд.

У циљу овога би требали органи и једне и друге земље на граници пооштрити будност.

Друг Радовић навађа да би ми са наше стране апсолутно пристали на ову сарадњу, а она би требала да иде истим везама и каналом као и сарадња по, политичком криминалу за ратне злочинце. Све остало би се могло и узајамно преписком надоместити.

Мађарски делегати изнашају, да је и код њих на том пољу криминалитета велика борба, због постојеће економске ситуације и струјања намирница са истока на запад, а валуте и сл. обрнуто. Каже да се појављује и такових лица која у униформи Совјетског војника или униформи официра Ј.А. врше разне црноберзијанске послове, па да њихови органи привредне полиције успоставе већу сарадњу са нашом делегацијом при СКК (Савезном контролном комисијом).

Изнаша да неко наше филмско предузеће из Југославије пребацује у Мађарску намирнице, маст и др., и у замјену добива аутомобиле и сл. материјал.

Друг помоћник Министра ДФЈ. предлаже да би сва она лица која једна држава ухвати на шверцу на свом подручју требало што хитније предавати органима безбедности његове земље, а трошкове спровођења да сноси свака земља за пратњу на свом подручју.

Након тога Мађарска делегација износи поруку г. Габош Петра Генерал мајора Мађарске политичке полиције, да би већ одмах са овом делегацијом или другче, али одмах, наша Влада изаслала неког свог делегата који би учествовао приликом истраге Мађарским ратним злочинцима и да би то било у интересу истраге и даљњег развоја утврђивања ратних злочина.

Делегација која поднесе меморандум такођер треба да се повеже са г. Командантом Мађарске политичке милиције.

На ово друг Помоћник одговара, да ће овом предлогу се настојати изаћи у сусрет, и да ће о томе најпречим путем бити упознат г. Командант Мађарске Политичке милиције.

Р. Миоковић, записничар“ 
Већ следећег дана, 9. новембра, у Министарству унутрашњих послова ДФЈ под Каб. бр. 1355 заведен је ПРОТОКОЛ о закључцима разговора од претходног дана. Занимљиво је да је сачињен у два примерка и то оба на српском језику. ${ }^{5}$ И овај документ доносимо у целини:

„На предлог Господина Министра унутрашњих послова Демократске Федеративне Југославије, дошло је дана 8 . новембра 1945. године у Београду до састанка претставника једног и другог ресора.

Делегацију Министраства унутрашњих послова ДФЈ чинили су: 1. МИЛОШ РАДОВИЋ, помоћник Министра; 2. ЂУРО СТАНКОВИЋ, начелник Одељења и 3. СВЕТОЗАР ЧОБРДА, шеф Одсека. Делегација је била снабдевена пуномоћјем К. бр 1349/45 од 8. новембра 1945. године.

Делегацију Министарства унутрашњих послова Мађарске сачињавали су: 1. др ХОРТОБАЂИ ЕНДРЕ, заменик шефа политичког Одељења Начелника Комесаријата државне полиције у Будимпешти, 2. ХОНИГСБЕРГ ОТО, виши чиновник и 3. ИШТВАН ДЕНЕШ, виши чиновник полиције. Делегација је била снабдевена пуномоћјем Министаства унутрашњих послова Мађарске бр. 143.323/45 И.Б.М. IV/12 од 1.новембра 1945. године.

Дискусија је вођена према Дневном реду утврђеном у акту Господина Министра унутрашњих послова Мађарске бр. 143.323/45 који гласи: Извештавам да изаслата лица /наводе се имена лица означена у пуномоћју/ долазе у Југославију са циљем да изврше следећи задатак: 1 . да успоставе везу са југословенским полицијским и политичко-полицијским властима. 2. да сакупе податке помоћу југословенских полицијских и политичко-полицијских власти против оних лица тј. мађарских јавних службеника, полицајаца жандарма, агената, војне протушпијунаже К-остаљаца и осталих војних и грађанских лица која су била на служби или вршљала у Војводини. 3. да се донесу већ сакупљени подаци. 4. да се сакупе подаци о ратним злочинцима југословенске народности, који се евентуално крију у Мађарској. Након исцрпне дискусије по свим тачкама дневног реда донесени су следећи закључци: $\mathrm{A} /{ }^{6}$ Досије са именима и подацима мађарских фашиста, оглашених од Државне комисије за утврђивање ратних злочинаца окупатора и њихових помагача Д.Ф.Ј. биће ускоро достављен Влади Мађарске са захтевом да се лица оглашена за ратне злочинце предају Влади Југославије на одговорност и свима њима изрекла заслужена казна од народног суда народа над којим су чинили злочине. Овај досије предаће Влади Мађарске два за то опуномоћена лица, која ће, што ће се накнадно утврдити, евентуално дуже остати у Мађарској да са мађарско полицијско-политичким властима сарађују на проналажењу и екстрадицији за Југославију свих тражених лица. Б/ Министарство унутрашњих послова Мађарске радиће на томе да се захтев југословенских власти у погледу издавања свих ратних злочинаца који се данас налазе на територији Мађарске спроведе у потпуности. Ц/ Веза и сарадња обеју земаља у погледу издавања ратних злочинаца и даље полицијске сарадње треба да буде директна, као и до сада, ослобођена бирокрације и непотребних формалности. Ова веза и сарадња одвијаће се преко лица која је раније у том циљу делегирано при Савезничкој Контролној Комисији. Д/ Накнадне податке, које прикупе југословенске власти, а тичу се ратних злочинаца који се налазе на територији Мађарске, достављаће надлежни органи Југославије властима Мађарске са захтевом да се издају Југославији ради њиховог привођења и судског кажњавања. Е/ Уколико досијеом Државне комисије за утврђивање ратних злочина окупатора и њихових помагача ДФЈ, или другим накнадним актима исте врсте, небуду обухваћена сва она лица - мађарски држављани која су у својству одговорних функционера провела време окупације на територији Југославије, а за које, према подацима до којих дођу мађарске власти, постоје докази да су учествовали у злочинима против народа Југославије, било потребно да се подаци мађарских власти надопуне истрагом наших југословенских полицијско-политичких власти, мађарске власти ће досијее са подацима о таквим лицима достављати редовним путем југословенским полицијско-политичким властима које ће их након прикупљања података и проведене истраге - надопуњене, враћати мађарским полицијско-политичким властима на даљи поступак. У оваквим случајевима /надопуне досијеа мађарских власти/ није потребно да мађарске полицијско-политичке власти делегирају своје органе, који би такве

\footnotetext{
${ }^{5} \mathrm{AJ}, 110-746-803$.

${ }^{6}$ Сви документи у овој фасцикли писани су латиничним писмом.
} 
податке прикупљали непосредно у Југославији, јер ће то радити на бази досијеа мађарских власти, југословенске полицијско-политичке власти. Ф/ Југословенске полицијско-политичке власти прикупљаће на захтев мађарских власти, исцрпне податке о држању и владању појединих мађарских чиновника, који су за време окупације били одговорни функционери у Југославији и достављати их мађарским властима на даљу употребу и решење о томе дали ће дотични чиновник бити предат суду, отпуштен из службе и слично. Ово важи за оне мађарске чиновнике о којима су прикупљени такви податци да их на основу њих југословенске власти нису огласиле за ратне злочинце. Г/ Органи Министарства унутрашњих послова ДФЈ, као и органи Министарства унутрашњих послова Мађарске, обавезују се да ће једни другима у борби противу криминала (хотелских крадљиваца, трговаца белим робљем, фалсификатора новчаница, хартија од вредности, путних исправа, шверца валутом, робом и сл.), који је уперен противу друге државе сауговорнице указивати сваку помоћ и сигнализирати сваку опасност, као и извештавати о резултатима проведених истрага, који би за другу државу биле од интереса и послужиле успешном сузбијању свих криминалних случајева.

Дискусија по свим предњим питањима, у вези доношења наведених закључака, била је пуна узајамног разумевања и прожета срдачним и пријатељским намерама.

\section{СМРТ ФАШИЗМУ - СЛОБОДА НАРОДУ !}

У Београду, дне 8. новембра 1945 год.“

Следе потписи трочланих комисија обе државе, али је према овом документу Протоколу додат извод из Досијеа Државне комисије за утврђивање ратних злочина окупатора и њихових помагача ДФЈ са именима 133 ратна злочинца ${ }^{7}$, који је предат делегацији Министарства унутрашњих послова Мађарске. Протоколу је додат још један прилог који доносимо такође у целини:

„овај Протокол обавезује и једну и другу страну угововорницу уколико Протокол буде потврђен потписом Господина Министра унутрашњих послова Мађарске, о чему ће Министарство унутрашњих послова Мађарске обавестити службеним актом Министарство унутрашњих послова Демократске федеративне Југославије.

За Министраство унутрашњих послова Мађарске

Др. ХОРТОБАЂИ ЕНДРЕ, с.p.

Оверава препис: М. Димитријевић

За Министарство унутрашњих послова ДФЈ

МИЛОШ РАДОВИЋ, Помоћник Министра, с.р.

Мађарски министар унутрашњих послова актом бр. 7/45, пов. IV.12.МУП обавестило је министра унутрашњих послова ДФЈ о својим ставовима. 'Изасланици и опуномоћеници г. Министра водили су у Београду 8. новембра 1945. год. преговоре по предмету трагања и хватања починитеља мађарских држављана који су у Југославији починили ратне злочине. Споразуми постигнути у току преговора унешени су у записник у Београду 9. новембра 1945. године и овај записник су потписали од стране пуномоћника југословенског Министра унутрашњих послова г. Милош Радовић, Помоћник Министра унутрашњих послова, а са стране мојих изасланика пак Др. Хортобађи Ендре.

На основу два додатка - прилога, који су прикључени записнику споразуми који се налазе у записнику обавезани су за обе стране, само у том случају, када ове закључке - споразуме потврди и одобри својим потписом и Мађарски Министар унутрашњих послова.

Част ми је известити г. Министра да сам споразуме наведене у горе назначеном записнику по предмету сарадње Југословенске и Мађарске милиције, са своје стране у целости прихватио.

С обзиром на то, да је по случајевима екстрадиције надлежан поступити мађарски Министар правде преко мађарског Министра спољних послова и пошто се указује потреба и закључења конвенције - споразума о екстрадицији, молим г. Министра да подејствује да Влада Федеративне Југославије у циљу закључења конвенције - споразума о екстрадицији ступи у контакт са мађарском Владом.

\footnotetext{
${ }^{7}$ Списак се не налази у фасцикли.
} 
Молим г. Министра да прими изразе мога високог поштовања:

Будимпешта, 1945 год. 8. новембра

Препис оверава Милан Јорговић“8

Министарство унутрашњих послова ДФЈ актом Каб. бр. 1355 од 11. децембра 1945. године обавестило је Одељење заштите народа Југославије, тј. потпуковника Ђуру Станковића, о свим овим активностима те су активности у вези са проналажењима, изручењима и касније суђењима подигнути на међудржавни ниво.

\section{Извори и литература:}

Kasaš, Aleksandar, Mađari u Vojvodini 1941-1946, Novi Sad 1996.

Рокаи, Петер, Ђере, Золтан, Пал, Тибор, Касаш, Александар, Историја Мађара, Београд 2002.

Šajti, Eniko, Delvidek 1918-1947, Novi Sad 2010.

\footnotetext{
${ }^{8}$ AJ, 110-746-803.
} 


\title{
A PROTOCOL ON EXTRADITION OF WAR CRIMINALS SIGNED BETWEEN THE DEMOCRATIC FEDERAL YUGOSLAVIA AND HUNGARY, FROM NOVEMBER 1945
}

\begin{abstract}
Summary
The issue of the research, finding war criminals for the crimes committed by Hungarian invaders in the territory of Yugoslavia, especially in Backa, in January 1942, had burdened relations between the two countries since the fall 1944. However, only at the end of the following year, this issue raised to the interstate level, i.e. a decision of AntiHitler coalition started to be implemented, which prescribed that the war crimes would be tried in the countries where they had been committed. The text explains important documents which authenticate that the Ministries of DFY and Hungary were willing to cooperate, especially concerning the activities on the eve of the upcoming Peace Conference.
\end{abstract}

Keywords: Hungarian-Yugoslav relations at the end of The World War II, raid in 1942, war crimes, The Protocol on extradition of war criminals between DFY and Hungary. 